\title{
EFFICIENCY OF ETHANOLIC EXTRACTS OF VEGETABLES FOR THE IN VITRO CONTROL OF THE PHYTOPATHOGENIC FUNGUS (FUSARIUM VERTICILLIOIDES)
}

\author{
FERNANDO SERNAQUÉ, ANA APAZA, LUIS SOLIS, WILVER AUCCAHUASI
}

Universidad César Vallejo, Lima, Perú

\begin{abstract}
In the present work the efficiency of the ethanolic extracts of Allium sativum, Allium cepa and Zingiber officinale was evaluated on the mycelial growth of the fungus Fusarium verticillioides, said phytopathogen has the power to infect and cause disease in Zea mays crops. The agar dilution technique was used, 5 repetitions were made by extract and dose, which were measured in 3 different times, in addition to the two-factor ANOVA experimental design with a level of significance of $\alpha=0.05$. The ethanol extract of Allium sativum showed an inhibition in the mycelial growth of the fungus in $100 \%$ with the dose at 13\% (V/v), being its lower inhibition in mycelial growth an average of 76.05\% with the dose at $11 \%(V / v)$ on day 5. The ethanol extract of Allium cepa inhibited the fungus $100 \%$ with the dose at $10 \%(V / v)$ in its three days of measurement, being its lower inhibition in the average mycelial growth from $48.72 \%$ to $6 \%(V / v)$ on day 5 and the ethanolic extract of Zingiber officinale which had a better role in terms of the public effect inhibit in $100 \%$ with the dose at $8 \%(V / v)$ in Its three days of measurement, being its lower inhibition in mycelial growth average of $76.98 \%$ to $6 \%(V / v)$. The ethanolic extracts of the plants studied give the opening to a way of biological control of phytopathogenic fungi in conventional and industrialized agriculture.
\end{abstract}

KEYWORDS: Allium Sativum, Allium Cepa and Zingiber Officinale, Phytopathogen, Mycelial, Biocontrol

Received: Jun 08, 2020; Accepted: Jun 28, 2020; Published: Sep 05, 2020; Paper Id.: IJMPERDJUN20201076

\section{INTRODUCTION}

Conventional as well as industrial agriculture has been harmed by the development of large phytopathogenic pests, which alter growth in crop development, generating low-quality products and even crop mortality, which implies carrying out genocidal action remediation practices. using agrochemicals, as Gonzales (2014) points out that; pesticides have helped to contribute to the intact development of food products and fibers in a more feasible, abundant, economical and effective way, but their uncontrolled use has led to serious consequences of contradictory results, on the one hand it has managed to prevent the appearance of phytosanitary diseases that currently cause serious problems at the agro-industrial level.

At the same time, this phytosanitary treatment produces environmental impacts and risks in human health due to its different chemical compounds (active ingredients) that they present in their categories and biological objective to be treated, making them very toxic, as indicated by Del Puerto, Suárez and Palacio ( 2014) that; improper use by man means that these chemicals are dispersed in the environment and become pollutants for biotic (fauna and flora) and abiotic systems (air, soil and water), damaging their balance and posing a threat to the environment. Human health. On the other hand, it follows that synthetic pesticides interact in the short term on the surrounding environment where they are applied for their depredation, damaging all living components in their 
path, as well as contributing to the annihilation of various organisms sensitive to their exposure that may be beneficial for the attack of enemy pests.

Mainly one of the phytopathogenic pests that harm the cultivation of Zea Maize (corn) is fusariosis caused by the fungus Fusarium verticillioides, causing wilt due to the impediment of the fluid of water and nutrients in its anatomical structure of the species, caused by a vascular infection of the vegetable in which the fungus attacks directly from the root and ends up staying on the stem forming fungal colonies that lead to death. According to Jiménez et al (2012), he clarifies that; Among the diseases caused by this class, the most relevant are those of the vascular type, these by disrupting the transport of water and essential minerals through the host body produce symptoms such as wilt, decay and yellowing.

On the other hand, this disease is causing great economic losses worldwide because it is capable of causing the mortality of a crop by up to $90 \%$, fusarium wilt is one of the most deadly diseases of bananas and other crops worldwide., has caused losses in several agro-industries on different continents (Asia, Africa, the Middle East) raising concerns about the threat to the production and trade of this popular crop. (FAO, 2016).

However, a pesticide of plant origin that can intervene in the growth of Fusarium verticillioides has not yet been found, in most studies related to this topic, they have focused on other genera of fungi, in addition to the concentrations provided on efficiency issues. of extracts or essential oils has not shown a precise control in their evaluations, which is why the researchers are concerned. According to Pino, Sánchez and Rojas (2013) mention that there are many events on the biological activity of substances present in plants, but these active compounds have not been experienced in most cases, in addition, the information provided by some authors is only related with medicinal use, since more scientific research should be carried out from an ecological-chemical perspective to contribute with alternatives in our agroecosystems.

Currently, the Santa Juana orchard belonging to the Paramonga district, located in the Barranca province in the department of Lima, has been affected in large part of its plots by this phytopathogen of the fusarium genus, the neighboring inhabitants who benefit from daily practices for these inputs and that in a way they are supplied economically through the trade of their food products, they have had an imbalance in well-being, leading to chemical remediation practices or crop burning, contracting impacts on health and the environment, likewise This orchard is limited with the agronomic crops of sugar cane belonging to the "Paramonga" Industry, which speculates that there is poor maintenance of its crops, it is suspected that due to this, in recent years the number of manifestations of these diseases that are currently resisting in the environment.

\section{MATERIALS AND METHODS}

\section{Natural Control}

Pérez (2012) tells us that; The application of pesticides of plant origin has been practiced since our ancestors, in ancient China, Egypt, Greece, India and even all of Europe and North America, reporting that it existed 50 years before the appearance of chemical pesticides. These botanical genocides were used in ancient times due to the multiple advantages that man had; Sufficient availability of natural resources, easy accessibility, low production cost and low toxicity.

Currently its use has gained strength in the phytosanitary world, scientific advances have been studying its genocidal potential in phytopathogenic diseases through extracts of plant plants, essential oils and even beneficial microorganisms capable of fighting pests, as mentioned by Borrego (2015); their worldwide use of biocides has increased every day, they are currently used as insecticides, fungicides, bactericides and this is due to their low resistance that they 
generate in living organisms, humans are less exposed to toxicity, they are effective in its genocidal power and are compatible with other control methods.

\section{Botanic Fungicides}

Celis et al (2008) mention that plants have numerous naturally occurring chemical compounds, in which they can be used to counteract varieties of phytopathogenic diseases in crops, their protective and repellent effect ranges from acute toxicity as well as its controlling power for the growth and development of fungi, where even said effect also inhibits the proliferation of bacteria and viruses.

The application of botanical fungicides is any biological agent of plant origin, which controls pests and diseases of crops, which can be used in the form of natural extracts or transgenic plants, it is an ecological alternative that was used for the control of insects and which are now destined for a great diversity of genocidal uses in microorganisms that impede the development of plant growth.

\section{Vegetable Ethanolic Extracts}

According to Iturbide et al (2017); The preparation of ethanolic plant extracts that are extracted from simple chemical processes opens the way to a biocontrol of phytopathogens in intensive agriculture, since it has demonstrated a high effective power against the development of infectious fungi, bacteria and nematodes, isolated in a wide diversity of crops. Plant extracts in many wild plants have been shown to have a fungitoxic effect on varieties of patho systems. Rodríguez, Morales and Ramírez (2010) tell us that plant extracts for pest control promote sustainable agriculture due to their high effectiveness, low cost and non-impact on the environment.

Likewise, Cazar et al (2014) comment that various pesticides are prepared from plant extracts, where these present combinations of active ingredients extracted by means of a suitable solvent, so it is then distilled and the residue or crude extract is adjusted at one dose to be subjected to in vitro bioassays. On the other hand, according to Apolonio et al (2017) clarifies that it is of great importance to replace the use of chemicals with friendly alternatives such as plant extracts that attribute antifungal power, they do not persist in ecosystems and are biodegradable, since they present some compounds of volatile biological activity.

\section{Antifungal Properties of Vegetables}

\section{Garlic (Allium Sativum)}

Aller (2008) reports that Garlic, which is part of the liliaceae family of the genus Allium, in recent years has been subjected to scientific studies reporting that it may justify its use as an antifungal, antimicrobial, antithrombotic and antihypertensive agent.

Different species of fungi have been shown to be sensitive to garlic because this species has sulfurous components such as alliin, which is converted to allicin by the enzyme allinase. This mentioned substance is what characterizes it for its antifungal property, as mentioned by Figueroa et al (2015); The healing or medicinal qualities of garlic are due to the sulfur groups that contain, such as allicin and ajoene, active substances that are created when they are crushed, crushed, fermented or cooked. The antimicrobial action of this substance is inhibiting some enzymes that cause infections caused by fungi, viruses or bacteria. 
Meriga, Mopuri and Muralikrishna (2012) reveals that; Recent studies show that Allium sativum is not only beneficial as a medical treatment, but it is also used in different crops as a repellent against different health diseases due to the presence of volatile chemical substances.

\section{Onion (Allium Cepa)}

Quintana et al (2010); The use of this vegetable in fungi has affected development stages such as spore germination, mycelial development and sporulation. The oils or aqueous extracts of Allium cepa have antifungal effects to combat certain phytopathogenic species due to the fact that it has organosulfur compounds that also exert different biological effects such as inhibition of the proliferation of tumor cells, microbial and antioxidant effects.

Jerez et al (2017); Onion has its biological active power thanks to two large chemical groups; the flavonoids and sulfoxides, within the flavonoids is the quercetin and it is the one that represents in its entirety the power in addition there are also the polyphenols that are present in the bulbs that are organic plant compounds that have also demonstrated bioactive effects. Avila et al (2011) mention that flavonoids are considered by man as a phytomedicine because their various studies have reported that they possess antifungal activities in the phytopathogen fusarium.

\section{Ginger (Zingiber Officinale)}

Ramírez et al (2011); Ginger (zingiber officinale) has shown effects on inhibition regarding the development of numerous types of fungi and bacteria that cause ailments in animals and plant crops (at field and post-harvest level), in addition this species evidences anticancer and antiviral activity due to its active components. The extracts or essential oils of ginger are of great interest when you want to talk about medicine since their properties associated with consumption have antioxidant, antimicrobial, antispasmodic, etc. power, it is due to the presence of some chemical substances present in the vegetable, such as gingerol and shogaol.

According to Garcia et al (2013); explains that ginger is a vegetable that has antifungal effects on 60 pathogenic microorganisms tested, including achieving to the point of controlling Fusarium verticillioides and its production in fumonisins B1 (FB1), B2 (FB2) and B3 (FB3), FB1; which is the most toxic and is found in high levels), it also alters its morphology of microconidia, through the use of its essential oil.

Zambrano (2015) argues that; The chemical properties (gingerol and shoagol) present in ginger have made this species relevant and applied in the medicinal industry because it has phenolic components in which it is characterized by its antimicrobial power, causing hyperacidification at the interface of the plasma membrane of the microorganism.

\section{Phytosanitary Aspects of Corn (Zea Mays)}

The highly produced and distributed cereal is corn, which is located worldwide in the third place of production followed by wheat and rice, with the largest producers in the country of Romania with approximately 9 million tons per day, the Appropriate uses that are generally for the food industry and for conversion to fuels as Brazil does. However, this species has suffered many ailments in terms of insects, viruses, mites, fungi, etc. Among the most damaging is the genus Fusarium verticillioides, as indicated by Figueroa et al (2010), that among the diseases that have manifested themselves in a greater percentage are the phytopathogens of the genus Fusarium, so that it is found mainly in the substrate and at times it may be linked to rotting or wilting of the crop. 
Most pests that feed on corn can be divided into three groups; those that feed from the aerial part of the foliage, those that attack from the stem part, and those that finally are in the ground and enter through the root and cause vascular infection of the plant. Currently one way to counteract plant pathogenic diseases is to have biological information about pests and how it is introduced in each growth process.

\section{Fusarium Verticillioides Entry Routes}

According to Torres et al (2014) reports that the fungus uses various access routes to the corn plant to colonize and initiate its parasitic action, thus causing diseases throughout its process, one of the most clarified routes are through:

Seedling infection occurs from and during the germination of corn silver, since the fungus remains in the soil or in the seed, it remains positioned to contaminate the plant, directly penetrating the pericarp (outer part of the fruit or seed ) and after the cells present in the skin of the root, after the third day when these seeds are sown with the phytopathogens present, the hyphae begin to colonize the cells of the parenchyma of the escutello reaching the cortex, however the colonization of the endodermis and vascular areas rarely occur. Between 25 to 30 days, the corn plant begins to show symptoms of rot.

The infection of the corn plant is through stigma, being the most common route where the fungus attacks, this happens when the airborne harmless and the conidia are transported through the rain, deposited on the stigma of the plant, facilitating entry into the hyphae of the fungus and pericarp cells.

The infection of the stem and ear by mechanical damage, occurs with the feeding of insects causing damage to the plant through which it will attack Fusarium verticillioides, so these insects act as vectors, since the fungus lasts in external bodies as del: sweeping worm, corn worm, thrips and weevils; its function being to disperse the fungus in the plant.

\section{Toxic-Pathogenic Action}

Fusarium verticillioides generates large amounts of lytic enzymes and toxins that contribute to the infectious development of the fungus. Among the most abundant substances are fusaric acid, fusarin $\mathrm{C}$, naphthoquinones, fumonisins and moniliformin. Solano et al (2011) state that the species of the genus Fusarium, being a saprophyte, synthesizes metabolites with highly toxicibiological components, these metabolites are pigments, mycotoxins and even antibiotics in some species, and compounds with ring structure whose biological activity has not been evaluated.

Fusarium veticillioides has the ability to produce amounts of toxins that help the infectious process, among the best known mycotoxics that this species produces are fumonisins, the latter mentioned being the most harmful. Sartori, Nesci and Etcheverry (2015) mention that one of the toxins generated by the fungus is fumonisins b1 and b2, presenting high toxicity for humans and animals when they eat these infected vegetables; producing mutagenic, teratogenic and carcinogenic effects.

\section{Bioassay}

\section{Agar Extract Dilution Technique}

This technique consists of diluting or "poisoning" the culture medium with the antifungal substances to be studied (homogenizing solutions), this test has been tested in many investigations, especially to measure the percentage inhibition in the growth of the filamentous fungus or sensitivity against chemical components, According to Gómez, Aracil and Gil 
(2009) reveal that the agar dilution method is the most optimal test when you want to control infectious microorganisms in vitro.

\section{Evaluation of Mycelial Growth Inhibition}

The test for inhibition of mycelial growth is based on analyzing how much the substance prevents the formation of mycelia (vegetative apparatus of the fungus) which is made up of conidia-forming hyphae (asexual spores), which is generally known as the phase reproductive of the fungi, it is used in laboratory experiments through a control test and another in treatment of different drugs and doses in order to know the antifungal effect, according to Iglesias et al (2017); presents the following equation to calculate the percentage of inhibition of mycelial growth:

$$
\% I C M=\frac{C T T-C T E}{C T T} * 100
$$

Where:

\% ICM: percentage of inhibition of mycelial growth

CTT: mycelial growth in the control treatment

CTE: mycelial growth in the evaluated treatment

These results have a weight of 0 to 4 as stated by Moron (2017):

$0=$ no visible growth ( $100 \%$ inhibition of mycelial growth)

$1=$ poor growth $(75 \%$ inhibition of mycelial growth)

$2=$ moderate growth (50\% inhibition of mycelial growth)

$3=$ abundant growth (25\% inhibition of mycelial growth)

$4=$ similar growth of the control ( $0 \%$ inhibition of mycelial growth)

\section{RESULTS}

\section{Experimento Piloto}

A pilot experiment was carried out in order to guarantee efficient results when controlling the fungus Fusarium verticillioides, for this pre-test it was taken into account that the three ethanolic extracts were subjected to control with the same doses $(5 \%, 10 \%, 15 \%, 20 \%$ and $25 \%)$, which was only enough to analyze 3 days and measure its radial growth of the fungus under control tests, also for each extract and dose, we worked with 3 repetitions where the unit of measurement was in millimeters.

\section{Obtaining Samples Infected with Fusarium Verticillioides Fungi from Corn in the Santa Juana Orchard}

The first step was to observe the vegetations that possibly meet the characteristics of Fusarium verticillioides infection (wilt or rot) in the Santa Juana orchard, once identified, different samples of infected corn were extracted, whether in the part of the foliage, stem, or root. or vegetable (corn), where they were placed in a cooler to maintain certain environmental conditions of the fungus, for this process the greatest possible asepsis was used, in addition to using sterile gloves, white 
apron, disposable mask, alcohol, magnifying glass, camera ( mobile) and a field notebook, where they were subsequently transferred to the Plant Pathology Laboratory of the Agrarian University La Molina for their respective evaluations.

\section{Extraction Area for Infected Samples}

The infected corn samples were collected in the Santa Juana orchard located in the Paramonga District, Barranca province, Lima department, with coordinates $10^{\circ} 40^{\prime} 47.37$ "South $77^{\circ} 48^{\prime} 36.47^{\prime \prime}$ West.

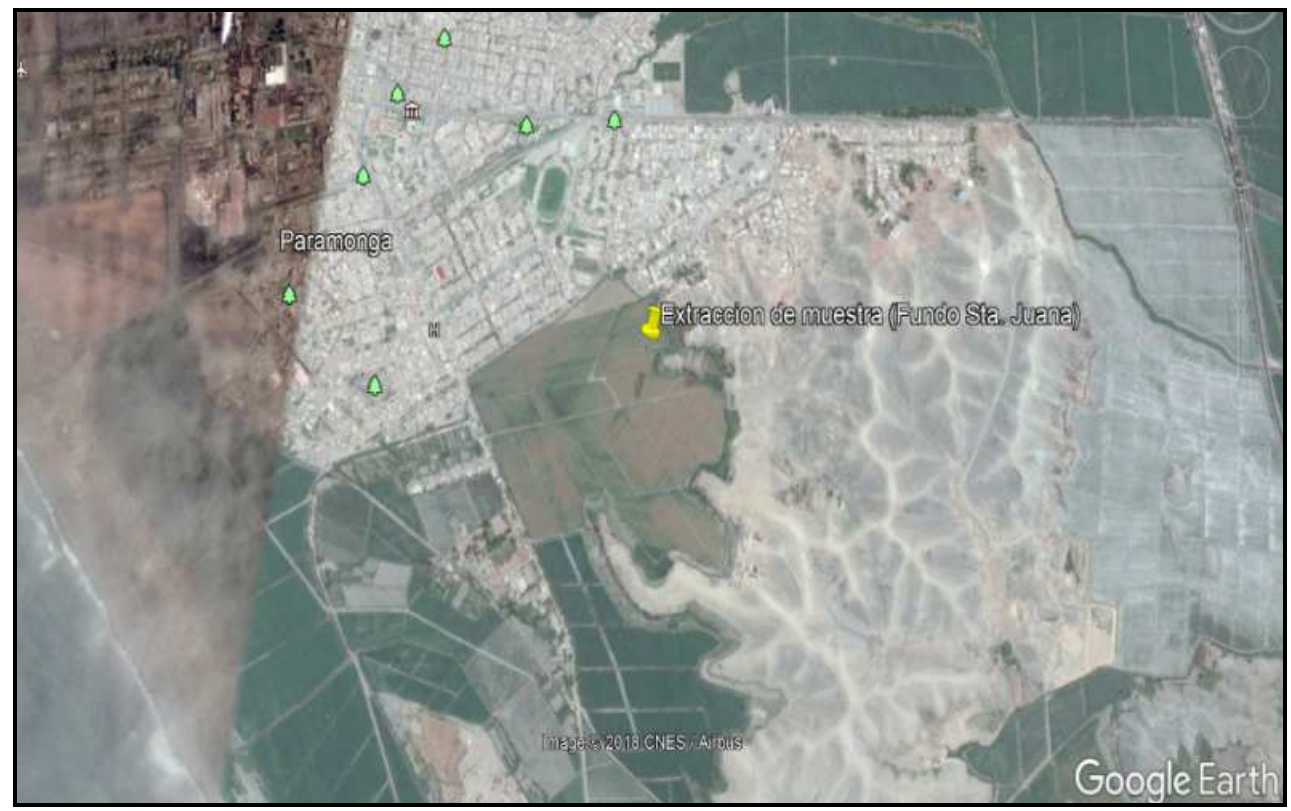

Figure 1: Geographical Location of the Infected Samples Extraction Area (Fundo Sta. Juana).

\section{Isolation and Identification of the Fungus Fusarium Verticillioides}

Once the samples infected with Fusarium verticillioides were extracted, contaminated tissues were cut, obtaining 2 to 3 pieces of $1 \mathrm{~cm} 2$ area, and then disinfected using the $1.5 \%$ sodium hypochlorite immersion technique for 1 minute, where It was rinsed 3 times with distilled water. On the other hand, the culture medium was prepared with potato dextrose peptone agar (see annex $\mathrm{N}^{\circ} 3$ ), in which the parts of the trimmed tissues were placed, this nutritional medium was used since it is convenient to assess the morphological aspect of the colony, due to its high carbohydrate content makes it achieve a better development (Marquez, De la Rosa and Mercado, 2007), they were sealed with parafilm tape to avoid contamination, then they were subjected to the incubator at temperatures of $26 \pm 2^{\circ} \mathrm{C}$ for 7 days. For their subsequent identification of genus and species, they had the support of a specialist in Plant Pathology and Nematology from SENASA.

\section{Preparation of Inoculum of Hyphae and Conidia}

The fungal colonies obtained from the infected corn were grown in petris boxes with Potato Dextrose Peptone Agar (APD $\mathrm{P})$ at $26 \pm 2{ }^{\circ} \mathrm{C}$ for 7 days, after their development the colonies in the petris boxes are covered with $10 \mathrm{~mL}$ of sterile $0.85 \%$ saline solution was shaken for two minutes and the surface of the fungal colony was rubbed with a sterile seeding loop, this suspension was transferred to a Falcon tube using a pipette and allowed to settle for 20 minutes (Fernández, 2005), after this process the inocula were adjusted to a tansmittance (T) of $50 \%$ at $530 \mathrm{~nm}$ with the saline solution. On the other hand, Cermeño and Torres (1998) in their various tests with mycelial fungi reveals that using this wavelength (530 nm) at 40 $50 \%$ transmittance, it allows to achieve an average cell suspension of 1 to $5 \times 106 \mathrm{CFU} / \mathrm{mL}$. 


\section{Preparation and Obtaining of Ethanolic Extracts of Vegetables}

For the preparation of ethanolic extracts the garlic bulbs (Allium sativum), Onion (Allium cepa) and ginger (Zingiber officinale) were used, for the three vegetables the same procedure was used as Cerqueira et al (2016) carried out in their research to control a species of the genus Fusarium.

Step $1.3 \mathrm{~kg}$ of each vegetable was weighed and peeled, they were disinfected with $1 \%$ sodium hypochlorite, then they were washed 3 times with abundant distilled water, once dried they were crushed in an Oster TM blender.

Step 2. Each proportion of the ground vegetable was macerated with 3 L. of $96 \%$ ethanol for 15 days in an amber glass container without an oxygen chamber.

Step 3. Only the raw extract of each macerated vegetable was extracted, for that the solvent had to be evaporated at $50^{\circ} \mathrm{C}$ with a pressure of 180 mbar by means of the Rotavapor Boeco Germany brand installed in the Biotechnology laboratory of the Cesar Vallejo University.

Step 4. Each pure extract is placed in sterilized amber containers where they were refrigerated $\left(4^{\circ} \mathrm{C}\right)$ for dosing and subsequent use in tests.

\section{Preparation of Dosages of Ethanolic Extracts of Vegetables}

To evaluate the efficacy of the ethanolic extracts of vegetables as antifungals, 5 doses were prepared for each one; (6\%, $7 \%, 8 \%, 9 \%$ and $10 \%)$ for the ethanol extracts of Zingiber officinale and Allium Cepa, and (11\%, 12\%, 13\%, 14\% and $15 \%$ ) for the ethanolic extract Allium sativum They were then diluted with PDAP for their respective evaluations.

Where to prepare the $10 \%$ dose for an extract it must be taken into account that each Petri dish is filled for $15 \mathrm{ml}$ of PDAP, then:

$$
\frac{10 * 15}{100}=1.5 \mathrm{ml} \text { de extracto }
$$

Therefore, $1.5 \mathrm{ml}$ of extract was subtracted, managing to homogenize $13.5 \mathrm{ml}$ of PDAP $1.5 \mathrm{ml}$ of extract. In the same way, this dosing technique was applied for the pilot experiment.

\section{Assessment of Percent Inhibition of Mycelial Growth}

For this test, $15 \mathrm{ml}$ of Potato Dextrose Peptone Agar (APD P) had to be homogenized in the petris boxes with each ethanolic plant extract in different doses, $(6 \%, 7 \%, 8 \%, 9 \%$ and $10 \%)$ for the extracts ethanolics from Zingiber officinale and Allium Cepa, and $(11 \%, 12 \%, 13 \%, 14 \%$ and 15\%) for the ethanolic extract Allium sativum, since the pilot test was taken as a reference. Once finished solidifying, $10 \mu \mathrm{L}$ of a Fusarium verticillioid suspension is applied by microsyringe, then they were incubated at a temperature of $26 \pm 2{ }^{\circ} \mathrm{C}$, the respective measurements were made in mm after incubation, for the results we subjected to an equation in which we found the percentage of inhibition of mycelial growth with respect to the control without treatment. 


$$
\% I C M=\frac{C T T-C T E}{C T T} * 100
$$

Where\% ICM: percentage of inhibition of mycelial growth, CTT: mycelial growth in the control treatment, CTE: mycelial growth in the evaluated treatment.

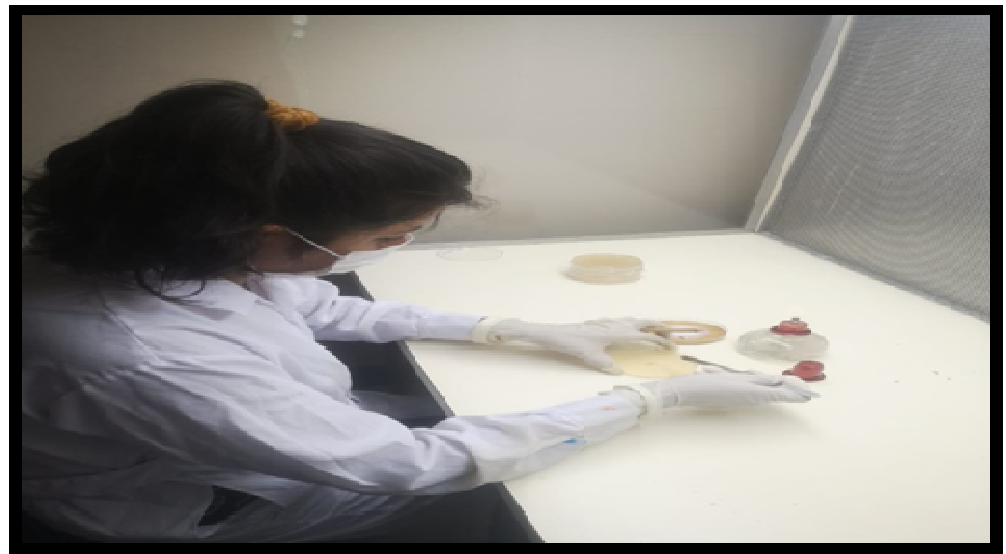

Figure 2: Preparation and Obtaining of Ethanolic Extracts of Vegetables.

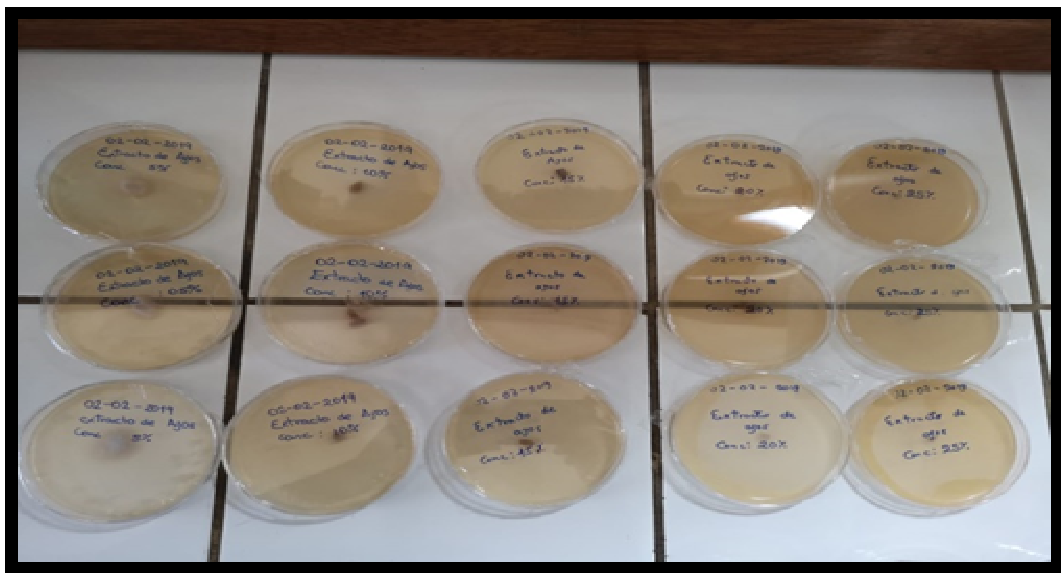

Figure 3: Pilot Test.

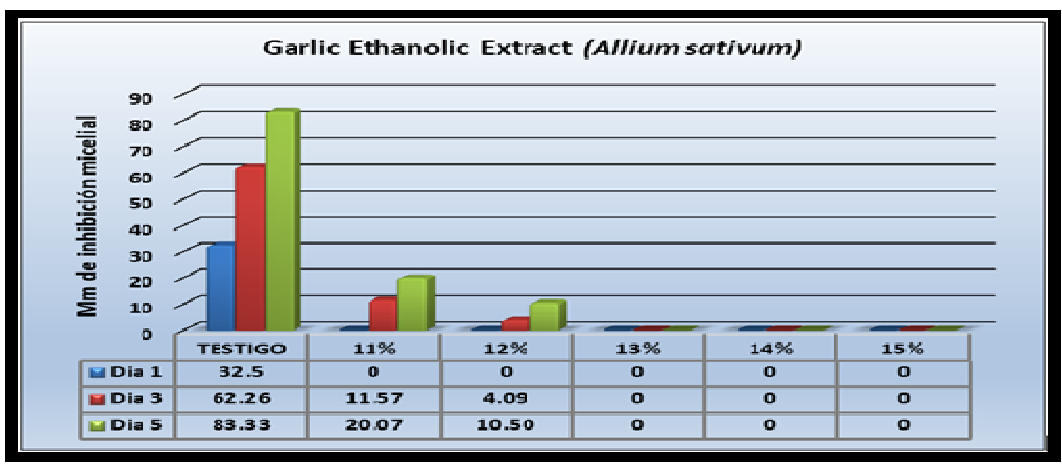

Figure 4: Histograms of Mycelial Growth Averages in Millimeters of F. Verticillioides in Garlic Ethanolic. 


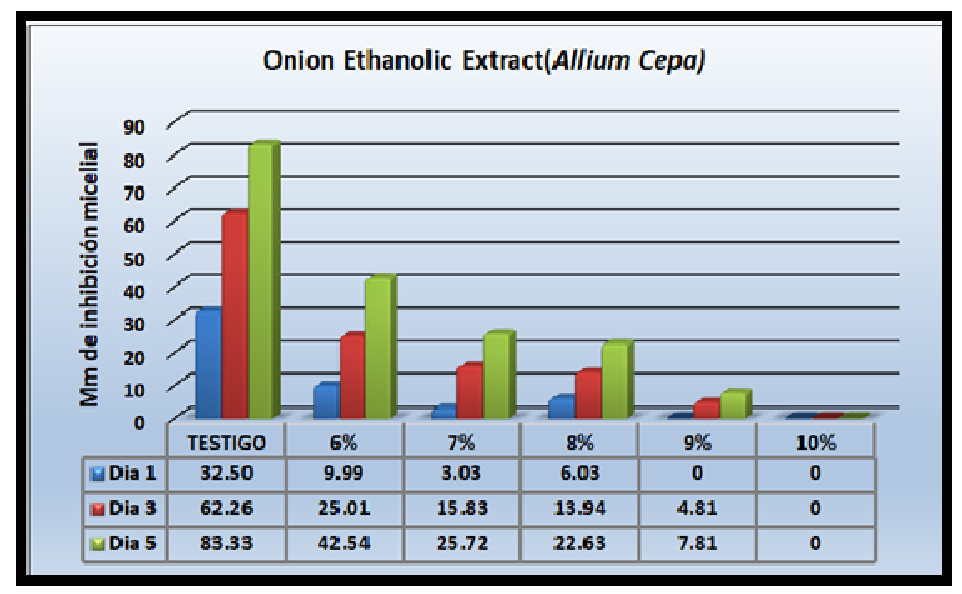

Figure 5: Histograms of Mycelial Growth Averages in Millimeters of F. Verticillioides in Onion Ethanolic.

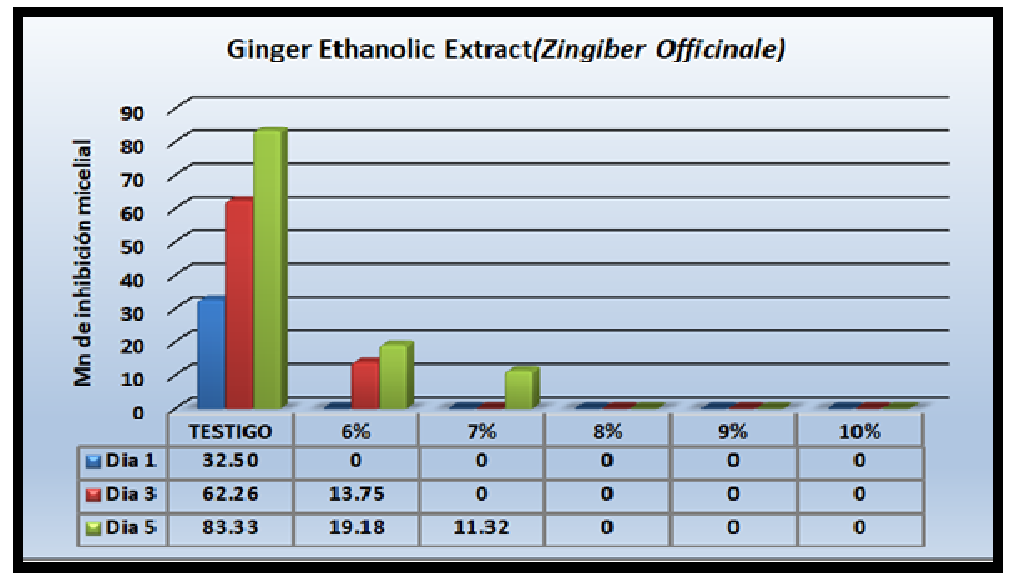

Figure 6: Histograms of Mycelial Growth Averages in Millimeters of F. Verticillioides in Ginger Ethanolic.

\section{CONCLUSIONS}

The efficiency of the ethanolic extracts of vegetables (Allium sativum, Allium cepa and Zingiber officinale) was evaluated for the in vitro control of the phytopathogenic fungus (fusarium verticillioides), where they were found to have antifungal effects in the 3 EEV's.

The ethanolic extract of Allium sativun showed efficiency from the $13 \%$ dose from the first day of incubation, inhibiting up to $100 \%$ of the pathogen's mycelial growth in relation to the control; which represents a millimeter growth of 0 in the petri dish with the treatment.

The ethanolic extract of Allium cepa showed efficiency from the $10 \%$ dose from the first day of incubation, inhibiting up to $100 \%$ of the pathogen's mycelial growth in relation to the control; which represents a millimeter growth of 0 in the petri dish with the treatment. 
The ethanolic extract of Zingiber officinale showed efficiency from the $8 \%$ dose from the first day of incubation, inhibiting up to $100 \%$ of the pathogen's mycelial growth in relation to the control; which represents a millimeter growth of 0 in the petri dish with the treatment.

The ethanolic extract of Allium cepa is not statistically efficient, since its value> 0.05 in the interactions "Dose * Time" explain that there is no significant difference in their data.

\section{REFERENCES}

1. ALLER, Luis. Garlic and cardiovascular risk. Anales de medicina Interna (Madrid) [en línea]. Mayo 2008, Vol. 25, Nro.5. [Fecha de consulta: 09 de octubre de 2018]. Disponible en http://scielo.isciii.es/scielo.php?script=sci_arttext\&pid=S021271992008000500010

2. APOLONIO, Isela [et al]. In vitro inhibition of Botrytis cinérea with extracts of wild grapevine (vitis spp) leaves. Revista mexicana de fitopatología [en línea]. Mayo 2017, vol.35 no.2. [Fecha de consulta:13 de octubre de 2018].Disponible en http://www.scielo.org.mx/scielo.php?script=sci_arttext\&pid=S0185-33092017000200170

3. AVILA, Mónica [et al]. Flavonoides con actividad antifúngica aislados de Piper septuplinervium (Miq) C. DC. (piperaceae). Revista colombiana química [en línea].2011, vol.40, no. 1. [Fecha de consulta:10 de octubre de 2018].Disponible en https://revistas.unal.edu.co/index.php/rcolquim/article/view/23146/28385

4. DEL PUERTO, Asela, SUÁREZ, Susana y PALACIO, Estrada. Effects of pesticides on health and the environment. Revista cubana High Epidemial [en línea].2014, Vol. 52, Nro.3. [Fecha de consulta: 28 de setiembre de 2018]. Disponible en http://scielo.sld.cu/scielo.php?script=sci_arttext\&pid=S1561-30032014000300010.

5. FIGUEROA Guadalupe [et al]. Caracterización de Especies de Fusarium Asociadas a la Pudrición de Raíz de Maíz en Guanajuato, México. Rev. mex. fitopatol [En línea]. 2010, vol.28, n.2 [Fecha de consulta: 12 de octubre de 2018], pp.124-134. Disponible en: http://www.scielo.org.mx/scielo.php?script=sci_arttext\&pid=S018533092010000200005\&lng=es\&nrm=iso

6. FIGUEROA, Kelly [et al]. Optical and structural characterization of Allium sativum L. nanoparticles impregnate in bovine loin. Acta Agrónoma [en línea]. Enero - Junio 2015, Vol. 64, Nro.1. [Fecha de consulta: 09 de octubre de 2018]. Disponible en http://www.scielo.org.co/scielo.php?script=sci_arttext\&pid=S0120-28122015000100007

7. GÓMEZ, José, ARACIL, Belén y GIL, Yolanda. Comparison between agar dilution and three other methods for determining the susceptibility of 228 clinical isolates of nonfermentig gram-negative rods. Journal of Infectious Diseases and Clinical Microbiology. [En línea]. Junio 2009, vol. 27, no.6. [Fecha de consulta: 15 de mayo del 2018]. Disponible en: https://www.sciencedirect.com/science/article/pii/S0213005X09001177

8. GONZALES, Andreína. Programa de concientización para el uso de plaguicidas en la comunidad de productores agrícolas de Butare, municipio Colina, estado Falcón, Venezuela. Red de Revistas Científicas de América Latina, el Caribe, España y Portugal [en línea]. Julio-Setiembre 2014, Vol.14, Nro. 3. [Fecha de consulta: 28 de setiembre de 2018]. Disponible en http://www.redalyc.org/articulo.oa? $\mathrm{id}=90432809003$.

9. IGLESIAS, Dianella [et al]. Actividad antifúngica in vitro de extractos de hojas de Citrus spp. Frente a Stemphyllium solani Weber. Revista centro agrícola [en línea]. Julio- septiembre 201, vol. 44, no. 3. [Fecha de consulta:12 de noviembre de 2018].Disponible en http://scielo.sld.cu/pdf/cag/b44n3/cag01317.pdf

10. ITURBIDE, Anygim [et al]. In vitro evaluation of extracts from the Lilium genus to control Fusarium Oxysporum. Revista Mexicana de fitopatología [en línea]. Septiembre 2017, vol.35, no.3. [Fecha de consulta:13 de octubre de 2018].Disponible en http://www.scielo.org.mx/scielo.php?script=sci_arttext\&pid=S0185-33092017000300611 
11. JEREZ, Adriana [et al]. Estudio de las propiedades benéficas en la cebolla (allium cepa I.) en el departamento de Tarija. Revista Ventana Científica. 2017, vol.8 no.13. disponible en http://www.revistasbolivianas.org.bo/scielo.php?pid=S2305$60102017000100003 \&$ script $=$ sci_arttext

12. JIMENEZ, P [et al]. Estrategias de control biológico de Fusarium Oxysporum en el cultivo de UCHUVA (Physalis pruviana). [en línea]. Primera edición, Colombia. 2012, pp. 14. [Fecha de consulta: 28 de setiembre de 2018]. Disponible en http://digitool.gsl.com.mx:1801/webclient/DeliveryManager?pid=64218\&custom_att_2=ditrec4.

13. MERIGA, Balaji, MOPURI, Ramgopal, MURALIKRISHNA, T. Insecticidal, antimicrobial and antioxidan activities of bulb extracts of Allium sativum. [En línea]. 2012, vol. 5, no. 5, pág. 391 - 395. [Fecha de consulta: 09 de mayo del 2019]. Disponible https://www.sciencedirect.com/science/article/pii/S1995764512600650

14. PINO, Oriela, SÁNCHEZ, Yaíma y ROJAS, Miriam. Plan Secondary metabolites as alternatives in pert management. II: An overview of their potencial in Cuba. Revista de protección vegetal [en línea]. Mayo 2013, vol.28, no.2. [Fecha de consulta: 12 de octubre de 2018]. Disponible en http://scielo.sld.cu/pdf/rpv/v28n2/rpv02213.pdf

15. QUINTANA, Eber [et al]. Inhibición del crecimiento de Penicillium chrysogenum por presencia de aceites Cinnamomun zeylanicun, Allium cepa y Cymbopogon citratus. Revista mexicana de micología [en línea]. Diciembre 2010, vol. 32. [Fecha de consulta:10 de octubre de 2018].Disponible en http://www.scielo.org.mx/scielo.php?pid=S018731802010000200007\&script=sci_arttext\&tlng=pt

16. RAMIREZ, Sandra [et al]. Actividad antifúngica in vitro de extractos de Origanum vulgare L., Tradescantia spathacea Swartz y Zingiber officinale Roscoe sobre Moniliophthora roreri (Cif \& Par) Evans et ál. Tecnología en marcha [en línea]. AbrilJunio 2011, vol.24, Nro. 2. [Fecha de consulta: 09 de octubre de 2018].Disponible en https://dialnet.unirioja.es/descarga/articulo/4835560.pdf

17. RODRIGUEZ, Aida [et al]. Antifungal activity of Acacia farnesiana extracts on the in vitro growth of Fusarium oxysporum $f$. sp. lycopersici. Revista Científica UDO agrícola [en línea]. 2012, Vol. 12, Nro.1. [Fecha de consulta: 28 de setiembre de 2018]. Disponible en https://dialnet.unirioja.es/servlet/articulo?codigo $=4277990$.

18. SARTORI, Melina, NESCI, Andrea y ETCHEVERRY, Miriam. Infección de Fusarium verticillioides y contenido de fumonisinas en granos de maíz de plantas con inflorescencias femeninas cubiertas y no cubiertas. Revista de la facultad de ciencias agrarias [En línea]. Junio 2015, vol.47, no.1. [Fecha de consulta: 12 de octubre de 2018]. Disponible en http://www.scielo.org.ar/scielo.php?pid=S1853-86652015000100018\&script=sci_arttext\&tlng=pt

19. SOLANO, Alma [et al]. La Pigmentación de Fusarium Verticillioides (SACC.) como factor de virulencia en plántulas de maíz. Revista de agronomía mesoamericana [En línea]. 2011, vol. 22, no.2. [Fecha de consulta: 12 de octubre de 2018]. Disponible en http://www.mag.go.cr/rev_meso/v22n2_297.pdf

20. TORRES, Diana [et al]. Fumonisinas - Síntesis y función en la interacción; Fusarium verticillioides. Revista Especializada en Ciencias [En línea]. 2014, vol.17, no. 1. [Fecha de consulta: 12 de octubre de 2018]. Disponible en http://www.scielo.org.mx/pdf/tip/v17n1/v17n1a6.pdf

21. ZAMBRANO, Eleonora. Genetic diversity of ginger (Zingiber officinale Roscoe.) At the molecular level: progress of the last decade. Julio - Diciembre, 2015 vol. 11, no. 2, p. 190-199. [Fecha de consulta: 09 de octubre de 2018].Disponible en http://dx.doi.org/10.18041/entramado.2015v11n2.22239 